\title{
STABILISASI DAN IDENTIFIKASI SEDIMEN HASIL PEKERJAAN PENGERUKAN
}

\author{
Ernesto Silitonga \\ Dosen Pengajar Jurusan Pendidikan Teknik Bangunan, Fakultas Teknik UNIMED \\ (ernestosilitonga@yahoo.fr)
}

\begin{abstract}
ABSTRAK
Penelitian ini direalisasikan dengan tujuan untuk mengumpulkan data sedimen hasil pekerjaan pen gerukan yang merupakan salah satu langkah yang diperlukan untuk mencegah pembuangan sedimen hasil pekerjaan pengerukan ke tengah laut seperti yang telah dilakukan selama ini. Sediment yang digunakan dalam penelitian ini adalah sedimen Pelabuhan Belawan, Sumatera Utara. Tahap awal yang dilakukan dalam penelitian ini adalah dengan mengidentifikasi karakteristik fisik dan kimia dari sedimen hasil pekerjaan pengerukan yang kmudian dilanjutkan dengan mengidentifikasi kadar polusi yang terkandung dari bahan penelitian. Tahap berikutnya yang direalisasikan adalah menganalisa reaksi yang dimunculkan dari bahan penelitian apabila sedimen dicampur dengan bahan pengikat umum (semen, kapur). Hasil TCLP, memperlihatkan beragam tingkat polusi dari sedimen, tingkat polusi tergantung pada lokasi dimana sedimen tersebut dikeruk, sedimen Pelabuhan Belawan dapat dikategorikan sebagai limbah berbahaya dengan kadar Copper $(\mathrm{Cu})$ dan Cadmium $(\mathrm{Cd})$ yang cukup tinggi. Penggunaan bahan pengikat (semen dan kapur) dalam campuran, imenunjukan berbagai ragam peningkatan performa dari sedimen, hasil penlitian menunjukkan bahwa kadar polusi berpengaruh negatif terhadap peningkatan performa yang dihasilkan.
\end{abstract}

Kata Kunci : karakteristik mekanik, karakteristik kimia, Sedimen hasil pengerukan, TCLP

\begin{abstract}
This research was realized with the aim to collect sediment data handiwork gerukan pen which is one of the necessary steps to prevent the dumping of sediment dredging work results into the sea as it has done over the years. Sediment used in this study is a sedimentary port of Belawan, North Sumatra. The initial phase in this research is to identify the physical and chemical characteristics of the sediment dredging kmudian the work continued by identifying pollution levels contained on the materials research. The next stage is to analyze the reaction realized that emerged from the study if sedimentary material is mixed with a binder general (cement, lime). TCLP results, show varying levels of pollution from sediments, pollution levels depending on the location where the dredged sediment, sediment Belawan Port can be categorized as hazardous waste with levels of Copper $(\mathrm{Cu})$ and Cadmium $(\mathrm{Cd})$ is quite high. The use of a binder (cement and lime) in the mix, imenunjukan a wide variety of performance improvements of sediment, penlitian results showed that the levels of pollution negatively affects the resulting performance improvement.
\end{abstract}

Keywords: chemical characteristics, mechanical characteristics, sediment dredging, TCLP 


\section{Pendahuluan}

Masalah utama yang selalui dijumpai dalam aktivitas pelabuhan adalah masalah pendangkalan yang disebabkan oleh sedimentasi.. Pendangkalan ini dapat menggangu alur pelayaran. Pekerjaan pengerukan merupakan salah satu pekerjaan yang sangat penting untuk kelangsungan operasi pelabuhan dan kegiatan ini dilakukan secara kontiniu untuk mencegah pendangkalan sehingga masalah ini tidak akan menggangu berjalannya kegiatan di pelabuhan. Problem pendangkalan pada pelabuhan ini merupakan masalah rutin dalam pelaksanaan aktivitas pelabuhan. Masalah sedimentasi atau pendangkalan ini menimbulkan masalah lingkungan lainnya, dimana limbah industri dan domestik ikut terbawa oleh sedimen yang berasal dari sungai-sungai yang bermuara di pelabuhan. Sungai sungai ini dimanfaaatkan untuk berbagai keperluan untuk kesejahteraan manusia sekitarnya. Namun, seiring dengan waktu, pertumbuhan industri dan jumlah penduduk, sehingga meningkatkan beban limbah industri dan domestik disungai-sungai dan menyebabkan sungai ini tercemar. Limbah domestik sebagai penyumbang terbesar pencemaran kedua sungai ini adalah timbunan sampah. Akibatnya seluruh limbah tersebut akan ikut terbawa oleh transportasi sedimen yang bermuara di pelabuhan. Secara otomatis, pembuangan sedimen ke tengah laut pada akhir dari proses pengerukan, dapat dianggap sebagai penyebaran limbah secara tidak langsung.. Tindakan pencegahan penyebaran limbah secara tidak langsung ini telah diterapkan semenjak tahun 1998 di berbagai Negara maju baik di Benua Eropah maupun Amerika (Colin 2003 dan Behmanesh 2008) dimana dalam penerapannya, semua material (sedimen) hasil proses pengerukan langsung di test untuk mendapakan kadar polusi dan berdasarkan tingkat polusi ini, dapat ditentukan apakah sedimen dapat dibuang kembali ke laut atau harus ditempatkan pada suatu daerah tertentu, dan dilakukan penstabilisasian, sehingga dapat diberdayagunakan sebagai material baru (Silitonga E. 2009*1 dan Zhibo 2008). Konfensi « Convention pour la protection du milieu marin de l'Atlantique du Nord-Est» pada tahun 1998 Konfesi ini dihadiri oleh Negara Jerman, Belgia, Denmark, Finlandia, Prancis, Inggris Iralndia Utara dan Swiss. dimana disepakati bahwa diperlukan tindakan pencegahan untuk pembuangan material hasil pekerjaan pengerukan di tengah laut. Setelah diadakannya Konfensi ini maka seluruh Negara anggota bersepakat bahwa negara-negara eropah memulai membuka lahan depot untuk tempat penimbunan sedimen-sedimen hasil pengerukan ini. Akan tetapi dikarenakan oleh volume dari sedimen hasil pengerukan ini semakin lama semakin meningkat, sehingga diperlukan tempat yang lebih luas unutk tempat penampungan (Detzner, H. D., A. Netzband, et al. 2004 dan Heise, S., E. Claus, et al. 2005). Setelah itu maka para ahli menyatakan bahwa solusi lahan depot untuk pennampungan penimbunan sedimen hasil pengerukan ini tidak efisien dan disamping itu mengeluarkan dana yang sangat tinggi untuk tempat penyediaan lokasi penimbunan. Solusi berikutnya dalam menanggulangi sedimen hasil pengerukan ini adalah dengan menemukan pendayagunaan yang tepat, baik dari segi ekonomi dan lingkungan. Akan tetapi pendayagunaan ulang sedimen hasil pengerukan ini tergantung oleh karakteristik dan kadar polusi material tersebut sesuai dengan hasil syarat yang butuhkan.

Dalam upaya menemukan pendayagunaan sedimen hasil pekerjaan pengerukan ini para peneliti masih terus berupaya melakukan penelitian-penelitian terkait seperti contoh : Silitonga, berusaha melakukan solusi dengan meneliti sedimen hasil pengerukan pelabuhan Cherbourg-Basse Normandie, Prancis (Silitonga E. et al., 2008*1). Penelitian ini disponsori oleh Pelabuhan Cherbourg-Basse Normandie, Prancis. Penelitian ini direalisasikan dengan menggunakan limbah industri lainnya, yaitu Abu terbang, yang berasal dari Pertambangan Batubara di Lorraine Prancis. Perusahaan pertambangan batubara Lorraine berusaha memberdayagunakan limbah mereka (abu terbang), dikarenakan volume penimbunan limbah ini setiap tahunnya semakin meningkat. Selain mengidentifikasi karakteristik origin dari sedimen hasil pengerukan, penelitian ini juga mengidentifikasi pengaruh dua tipe kapur yang berbeda yang digunakan dalam percobaan ini.. Penelitian lainnya dari Silitonga (Silitonga E. et al., 2008*2) memperlihatkan bahwa, penggunaan abu terbang dalam campuran sangat berdampak positif untuk meningkatan ketahanan daya tekan pada sampel yang dicampur dengan abu terbang. Dimana peningkatan terhadap daya tekan 
berbanding lurus terhadap peningkatan persentase campuran abu terbang di dalam sampel. Abu terbang juga terbukti meningkatkan ketahanan sampel pada pergantian kondisi lingkungan yang ekstrim. Melalui percobaan Freeze-Thaw test, dengan pergantian suhu dari $10^{\circ} \mathrm{C}$ ke $-10^{\circ} \mathrm{C}$ setiap 8 jam, sampel dengan campuran Abu Terbang menunjukkan kinerja yang ketahanan yang sagat tinggi akan kondisi udara yang ekstrim. Selain ini kepekaan sampel terhadap air meningkat drastis. Hal ini dapat diperhatikan melalui percobaan Dry-Wet test. Dari hasil percobaan ini, dapat kita perhatikan bahwa ukuran abu terbang yang tergolong sangat kecil (0,5 sampai $200 \mu \mathrm{m})$. Kelebihan abu terbang inilah yang bertanggung jawab atas peningkatan kekuatan sampel akan pergantian suhu ekstrim. Kecilnya ukuran abu terbang, memberikan peluang kepada material ini untuk dapat mengisi celah-celah atau ruang kosong dalam matrix sampel. Dengan terisinya celahcelah ini, maka matrix benar-benar solid sehingga tidak ada celah untuk air dapat masuk untuk mengisi ruang-ruang kosong

Beberapa faktor yang dapat memberi dampak negatif pada sampel dalam memperoleh performa yang diharapkan. Berdasarkan Penelitian yang dilakukan oleh Silitonga. (Silitonga E. et al., 2009) ${ }^{{ }^{1}}$ yang bertujuan untuk menstabilisasi sedimen hasil pengerukan di pelabuhan Cherbourg-Basse Normandie, Prancis, dengan menggunakan abu terbang sebagai binder Pengikat. Hasil Penelitian ini menunjukkan bahwa persentase kadar polusi dalam sedimen dapat memperlambat atau proses reaksi kimia yang terjadi dalam matrik untuk mendapatkan kekuatan dan kepadatan (solid). Sebaliknya dalam penelitian ini juga dibuktikan bahwa dengan ditambahkannya binder pozzolanic (abu terbang) dalam campuran sampel, selain meningkatkan performa mekanik juga menurunkan kadar polusi pada sedimen. Penelitian oleh Silitonga (Ernesto SILITONGA. et al., 2010) bertujuan untuk menemukan pendayagunaan sediment hasil pengerukan dari Pelabuhan Port En Bessin, Prancis dengan pertimbangan lingkungan, aman dan ekonomis. Hasil pengukuran distribusi granulometri dari sediment ini menggunakan alat pengukuran granulometri laser, dikarenan ukuran dari sedimen ini sangat kecil $(<200 \mu \mathrm{m})$. Pengukuran granulometri laser (foto 5) diambil dari 4 titik yang berbeda disekitar Pelabuhan.

\section{Metode Penelitian}

Metode penelitiaan yang diadaskan digunakan terdiri langkah-langkah dibawah ini :

1) Identifikasi masalah

Dalam tahap ini, masalah-masalah yang timbul dan terkait mengenai penggunaan ulang sedimen hasil pengerukan akan dibuat hipotesis yang akan ditindak lanjuti oleh penelitian dan ujicoba untuk mengklarifikasi hipotesis tersebut.

2) Pengumpulan data dan sumber pendukung. Penelitian penelitian ilmiah yang telah dilakukan di dalam ataupun diluar negri yang bersangkutan dengan pendayagunaan sedimen hasil pengerukan akan dikumpulkan dan lalu didaftarkan sebagai referensi untuk penelitian ini.

3) Pengambilan Sampel

Tahap ketiga dari percobaan ini adalah pengambilan sample (sedimen hasil pekerjaan pengerukan) penempatan titik tempat pengambilan sample sangatlah penting untuk mendapatkan hasil yang diharapakan. Untuk menentukan titik pengambilan sample, sebelumnya harus mendapat gambaran letak strategis penimbunan sedimen yang berasal dari sungai Belawan dan sungai Deli. Hal ini berguna untuk mendapatkan sample yang mewakili sedimen terpolusi dari dua daerah yang berbeda.

4) Identifikasi tipe penyimpanan dan pengeringan

Setelah tahap pengambilan sample, tahap berikutnya adalah menemukan sistem yang memadai dan efisien dalam upaya untuk mengurangi kadar air dari sediment. Seperti yang kita ketahui bersama, kadar air origin dari sedimen hasil pengerukan sangatlah tinggi, sehingga tidak memungkinkan untuk digunakan dalam campuran. Berbagai jenis sistem 'Dewatering' telah dilaksanakan di berbagai Negara (Mehta, ...). Pemilihan system 'Dewatering' ditentukan oleh beberapa faktor, yaitu: kwantitas material/ sediment yang dikeruk setiap tahunnya, dana yang tersedia dan Jeniis pendayagunaan ulang dari material/ sedimen.

5) Identifikasi karakteristik material dan binder yang akan digunakan.

a. Tahap pertama terdiri dari percobaan ini adalah, mengidentifikasi karakteristik/ propoerti mekanik, mineralogi dan kimia, dari material yang digunakan, dalam hal ini 
Sedimen hasil pengerukan dari Pelabuhan Belawan. Identifikasi properti fisik / mekanik dari material ini dilakukan dengan melakukan percobaan- percobaan yang umumnya dilakukan dalam pekerjaan teknik sipil, contohnya: identifikasi distribusi granulometri, identifikasi kadar material organik, identifikasi batas plastisitas dan likuiditas dengan metode Atteberg, percobaan bleu de methylene untuk mengetahui prilaku tanah liat yang terkandung dalam material, percobaan Proctor, California Bearing Ratio (CBR) dan lain-lain. Leaching test diperlukan untuk menentukan properti kimia dan kadar polusi dalam material.

b. Tahap ketiga dari percobaan ini dimulai dengan melakukan identifikasi dari binder (bahan pengikat) yang akan digunakan dalam penelitian ini (semen, kapur ataupun binder pozzolonic). Hal ini diperlukan untuk mengetahui kelas atau kinerja dari binder yang digunakan, dan agar nantinya dapat dibandingkan dengan hasil percobaan setelah binder tersebut dicampur dengan sedimen hasil pekerjaan pengerukan.

6) Penentuan formulasi dari campuran.

Setelah mengidentifikasi kinerja binder kemudian tahap berikutnya direalisasikan dengan mencampur sedimen dengan binder (bahan pengikat) campuran (binder) yang umum digunakan dalam pekerjaan bangunan, seperti semen dan kapur. Binder ini diharapakan dapat mengurangi kadar polusi dari material/ sedimen yang digunakan.. Tahap ketiga ini direalisasikan dengan tujuan untuk mengetahui prilaku material/ sedimen terhadap kehadiran binder dalam campuran. Percobaanpercobaan mekanik untuk mengukur ketahanan sebuah material yang akan digunakan dalam pekerjaan bangunan akan direalisasikan. seperti percobaan daya tekan, daya geser, percobaan permeability, dan tentunya akan dilanjutkan dengan percobaan kimia(leaching test) untuk mengidentifikasi kadar polusi yang ada disetiap campuran yang akan direalisasikan. Setelah percobaan diatas dilakukan, tentunya seluruh hasil percobaaan dikumpulkan dan di dianalisa, dan dengan pertimbangan dari segi skonomis maka campuran dengan kadar polusi terkecil akan dipilih menjadi campuran yang memiliki komposisi yang terbaik.

\section{Hasil dan Pembahasan}

\subsection{Pengambilan Sampel}

Pemilihan lokasi ini berdasarkan kondisi lokasi yang diharapkan dapat mewakiili kondisi yang diperlukan dalam mendapatkan sampel sesuai dengan perkiraan. Lokasi tempat pengambilan sampel adalah : lokasi Alur Kolam Citra Pelabuhan (L1) dan lokasi depot perbaikan kapal (L2)

Kedua tempat pengambilan ini berada di area Pelabuhan Belawan, Sumatera Utara. Namun sangat disayangkan untuk mendapatkan izin dalam mengambil sampel ini tidak mudah, untuk itu peneliti berusaha untuk mendapatkan sampel dari lokasi-lokasi lain disekitar PELABUHAN BELAWAN yang diperkirakan dapat mewakili kondisi seperti yang dimiliki lokasi Alur Pelayaran dan Lokasi Alur Kolam Citra.

\subsection{Karakteristik Origin}

a) Distribusi ukuran partikel

Hasil pengukuran distribusi granulometri dari sediment ini menggunakan alat pengukuran granulometri laser, hal ini dikarenan ukuran dari sedimen ini sangat kecil $(<200 \mu \mathrm{m})$. sehingga pengukuran ukuran material dengan menggunakan metode manual tidak akan memberikan hasil yang diharapkan. Pengukuran granulometri laser (Tabel 1) diambil dari 2 lokasi yang berbeda (L1 dan L2) dimana masing-masing diwakili oleh 4 sampel yang diperoleh dari 4 titik yang berbeda. Berdasarkan hasil pengukuran yang diperoleh maka dapat disimpulkan bahwa sedimen hasil bahan pengerukan dari pelabuhan Belawan ini terdiri dari $90 \%$ dari butir sedimen ini berukuran antara $66-78 \mu \mathrm{m}$. Hasil ini memperlihatkan bahwa ukuran dari sedimen ini dapat dikategorikan sangat kecil 
Tabel 1. Distribusi granulometri sedimen hasil pekerjaan pengerukan

\begin{tabular}{|c|c|c|c|c|}
\hline & PEB A-1 & PEB B-1 & PEB C-1 & PEB D-1 \\
\hline $\mathrm{D} 10(\mu \mathrm{m})$ & 2 & 1.92 & 1.5 & 2.2 \\
\hline $\mathrm{D} 50(\mu \mathrm{m})$ & 12 & 11.1 & 10.6 & 12.5 \\
\hline $\mathrm{D} 90(\mu \mathrm{m})$ & 78.4 & 66.7 & 72 & 75.6 \\
\hline $\begin{array}{c}\text { Fraction } \\
\text { argileuse } \\
(<2 \mu \mathrm{m}) \\
(\%)\end{array}$ & 10.7 & 10.6 & 13.8 & 9 \\
\hline $\begin{array}{c}\text { Fraction } \\
\text { silteuse }(2 \\
\text { à } 63 \mu \mathrm{m}) \\
(\%)\end{array}$ & 77.2 & 78.8 & 74.8 & 78.8 \\
\hline $\begin{array}{c}\text { fraction } \\
\text { sableuse } \\
(>63 \mu \mathrm{m}) \\
(\%)\end{array}$ & 12.6 & 10.6 & 11.5 & 12.2 \\
\hline
\end{tabular}

Selain itu, dengan memperhatikan gambar 3 maka dapat kita simpulkan bahwa ukuran dari sedimen yang diambil dari 2 lokasi berbeda tergolong dalam kelas yang sama $(66-78 \mu \mathrm{m})$ terlihat tidak terdapat perbedaan yang mencolok antara sampel yang diperoleh, dengan demikian dapat kita simpulkan bahwa sedimen ini tergolong homogeny.

\subsection{Karakteristik Mekanik}

a) Percobaan IPI dan Proctor

Percobaan California Bearing Ration (CBR) direalisasikan untuk mengidentifikasi nilai Indeks Portance Immediate (IPI) dengan kondisi kadar air yang maksimal. Nilai IPI sangat menentukan dalam penggunaan material dalam pekerjaan pembangunan jalan.

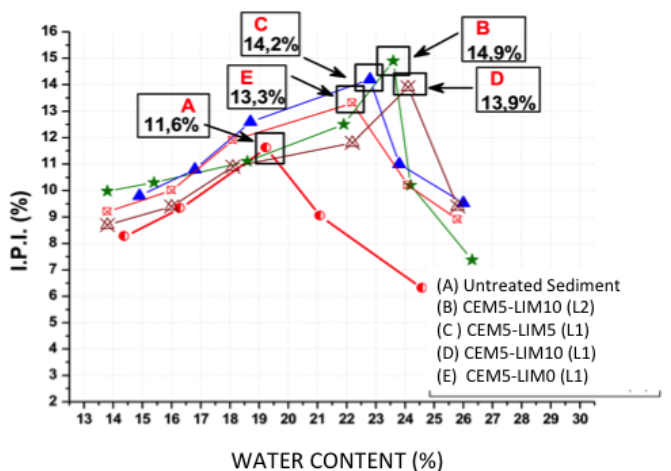

Gambar 1. Hasil percobaan California Bearing Ration

Pada gambar 1 hasil percobaan California Bearing Ratio (CBR) menperlihatkan bahwa nilai IPI meningkat sesuai dengan bertambahnya persentase binder yang digunakan. Hasil percobaan memperlihatkan bahwa nilai IPI yang tertinggi adalah sampel (B) dengan persentase binder 5\% sement dan $10 \%$ kapur untuk lokasi pengambilan sampe L2, Namun untuk sampel dengan persentase yang sama dengan lokasi yang berbeda (L1). Sampel dengan lokasi pengambilan L1, apabila kita perhatikan antara sampel C (5\% semen dan $5 \%$ kapur) sampel dan D (5\% semen dan 10\% kapur), hasil percobaan memperlihatkan bahwa dengan penambahan persentase kapur sebanyak $5 \%$ tidak memperlihatkan peningkatan nilai IPI yang signifikan sesuai dengan persentase penambahan kapur .Hal ini disebabkan oleh kadar polusi yang terdapat pada sedimen sehingga menggangu proses reaksi kapur. Penelitian sebelumnya menemukan bahwa penambahan binder kapur sangat membantu dalam menaikkan nilai $\mathrm{pH}$ sampel menjadi sangat tinggi $(\mathrm{pH}=12)$ dan hal ini memberikan dampak positif untuk kinerja binder lainya. Pengaruh binder kapur akan terus memberikan ketahanan ekstra selama $\mathrm{pH}$ sampel diatas 12, tingginya nilai $\mathrm{pH}$ ini mengakibatkan disolusi dari ion Kalsium, sedimen mengeluarkan alumunium dan silica yang nantinya akan bereaksi terhadap ion Kalsium sehingga membentuk C-S-H dan C-A$\mathrm{H}$. Kedua elemen ini yang mempunyai andil besar dalam memberikan ketahanan dan menjadi solidanya sebuah sampel, akibat kekuatan ikatan mereka merekat unsur-unsur lainnya. Teori ini tidak sesuai dengan hasil yang didaptkan dalam percobaan ini, seperti kita sebutkan sebelumnya, penambahan persentase kapur tidak memperlihatkan perbedaan peningkatan nilai CBR yang signifikan, Hal ini disebabkan oleh hadirnya elemen polusi yang sangat mengganggu dalam memperoleh kekuatan dalam waktu yang dekat.

b) Percobaan daya tekan (Unconfined Compressive Strength)

Percobaan daya tekan ini (UCS) direalisasikan untuk mengetahui peningkatan performa mekanik dari sampel, dan juga untuk mengidentifikasi efek yang diberikan oleh binder yang digunakan dalam performa mekanik. Hasil dari percobaan daya tekan (UCS) ini diperlihatkan pada gambar 2. Hasil percobaan ini khusu direalisasikan untuk 
mengidentifikasi dampak persentase semen yang ditambahkan kedalam campuran. Pada hasil percobaan UCS ini sampel yang digunakan hanya sampel yang diambil pada lokasi depot perbaikan kapal (L1), untuk mempermudah pengidentifikasian dampak penambahan semen dalam campuran, penggolongan peningkatan nilai daya tekan dikategorikan dalam 3 periode yang akan diperlihatkan pada gambar

c) Dampak kapur terhadap performa mekanik Penambahan kapur dalam campuran direalisasikan dengan pertimbangan bahwa penggunaan kapur telah terbukti selama ini dapat meningkatkan performa dari sampel yang digunakan. Hasil Percobaan Unconfined Compressive Strength diperlihatkan di gambar 3 dimana 5 sampel dengan formulasi binder yang berbeda. Persentase jumlah kapur didalam campuran dimulai dari $0 \%$ (CEM5LIM0), 5\% (CEM5-LIM5) dan 10\% (CEM5-LIM 10). Berdasarkan pengalaman peneliti dalam pekerjaan stabilisasi tanah, persentase kapur pada campuran diatas $10 \%$ tidak direkomendasikan, dikhawatirkan dengan persentase kapur yang terlalu tinggi dapat memprovokasi pembengkakan akibat reaksi yang ditimbulkan oleh kapur. Untuk mempermudah analisa, hasil percobaan daya tekan ini (UCS) ini dikategorikan dalam 3 periode (telah diterangkan di sub bab sebelumnya). Pada Periode curing age awal (a) nilai daya tekan (UCS) antara binder dengan persentase kapur $0 \%$, 5\% dan 10\% tidak menunjukkan perbedaan yang signifikan. Sampel dengan persentase semen $5 \%$ dan kapur 5\% dan dari lokasi L2 memperlihatkan nilai daya tekan yang tertinggi $(0,68 \mathrm{MPa})$ disbanding sampel dari lokasi L1.

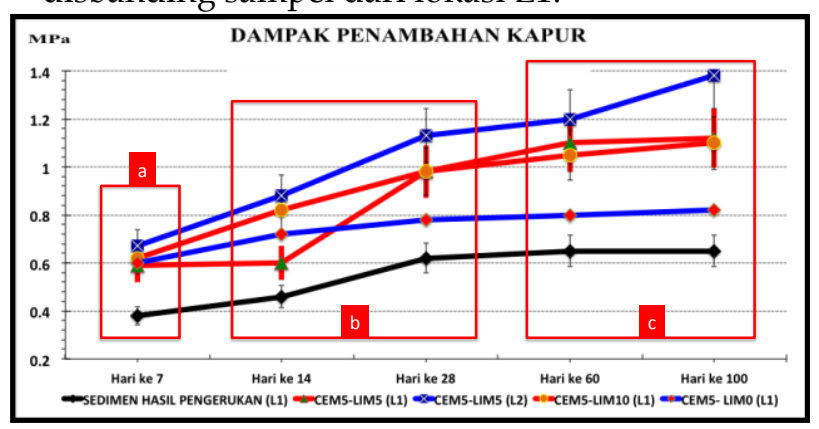

Gambar 2. Percobaan daya Tekan

Hal ini disebabkan oleh reaksi kapur dalam memberi peningkatan performa mekanik tergolong lambat. Reaksi kapur umumnya memerlukan waktu sekitar 60 hari (tergantung kadar reakstif dari kapur itu sendiri) untuk dapat memberikan hasil yang maximal. Reaksi kapur memprovokasi peningkatan $\mathrm{pH}$ sampel sehingga dengan waktu berjalan ion Kalsium dari matriks sedimen akan membentuk C-S-H dan $\mathrm{C}-\mathrm{A}-\mathrm{H}$, yang mempunyai peranan utama dalam peningkatan performa dari sampel. Hal ini menjelaskan mengapa tidak terlihat perbedaan yang signifikan pada nilai daya tekan dari beberapa sampel (dengan formulasi yang berbeda). Pada periode curing age awal (7 hari) reaksi kapur dalam menaikkan $\mathrm{pH}$ diperkirakan hanya membantu mengendapkan air yang terdapat dalam sampel sehingga sampel lebih cepat mencapai tingkat solid, sehingga memperoleh performa mekanik. Periode curing age menengah (14-28 hari) perbedaan nilai daya tekan semakin terlihat jelas, dimana sampel dengan persentase kapur sebesar $10 \%$ memperlihatkan peningkatan nilai UCS. Sampel dengan 5\% kapur dan 5\% semen (CEM5-LIM5) dengan sedimen berasal dari L1 tetap memperlihatkan nilai daya tekan terbesar, pada periode curing age menengah ini terutama pada hari ke 28 , hanya sampel dengan sedimen L2 ini yang melewati kekuatan daya tekas sebesar $1 \mathrm{MPa}$. Nilai daya tekan $1 \mathrm{MPa}$ merupakan batas yang diperlukan dalam penggunaan pembangunan jalan. Sampel sedimen dari lokasi L1 memperlihatkan kekuatan daya tekan yang hampir mendekati 1 MPa.Perbandingan antara sampel dengan sedimen L1 dan L2 memperlihatkan perbedaan yang penting, walaupun dengan formulasi yang sama ( $5 \%$ semen dan 5\% kapur). Hal ini disebabkan oleh tingginya tingkat polusi dari sampel dengan sedimen yang berasal dari lokasi alur kolam citra (L1). Berdasarkan pengalam peneliti, elemen polusi apabila mencapai jumlah tinggi akan mengganggu reaksi dari binder yang digunakan, baik itu reaksi semen ataupun reaksi kapur. Tingginya elemen penyebab polusi ini dapat memperlambat proses pembentukan clincker (pada reaksi hidratasi semen) dan menghambat kenaikan $\mathrm{pH}$ (pada reaksi kapur) sehingga hal ini menyebabkan terhambatnya sampel dalam mencapai performa mekanik yang maksimal. Hal ini dapat disimak dari tabel 2 dimana terlihat dari hasil Toxcity Characteristic Leaching procedure (TCLP) ditemukan bahwa sedimen berasal dari lokasi L1 jauh lebih berpolusi dari sedimen L2. Terutama Cadmium (Cd) dan Cooper $(\mathrm{Cu})$. Faktor ini yang 
menyebabkan terhambatnya reaksi binder (semen dan kapur) sehingga sampel dengan sedimen dari lokasi L1 (CEM5-LIM5-L1) menghasilkan nilai daya tekan (UCS) lebih kecil dari sedimen dari lokasi L2 (CEM5-LIM5-L2). Period curing age jangka panjang (60-100 hari) hasil percobaan memiliki pola yang sama dengan Period curing age menengah, sampel dari Lokasi L2 (CEM5-LIM5-L2) masih menunjukkan hasil percobaan daya tekan yang terbaik, diikuti oleh (CEM5-LIM5-L1) dan (CEM5-LIM10-L1). Sampel dari lokasi L2 (CEM5-LIM5-L2) menunjukkan peningkatan yang tinggi dari kekuatan terhadap daya tekan. Hal ini disebabkan oleh reaksi dari hidratasi dari kapur dalam menaikkan $\mathrm{pH}$ dan hydratasi dari ion Kalsium dan ion Alumunium lalu membentuk gel C-S-H dan C-A-H. Sampel dengan formulasi yang sama dengan sedimen dari L1 (CEM5-LIM5-L1) tidak memperlihatkan peningkatan daya tahan terhadap daya tekan sebaik sampel dari L2. Peningkatan nilai daya tekan pada hari ke 60 dan 90 disebabkan oleh reaksi hidratasi kapur, hal ini dapat dibuktikan dengan memperhatikan gambar 7 dimana evolusi daya tekan sampel tanpa ada campuran kapur $(0 \%)$ didalamnya (CEM5-LIM0), sampel ini hampir tidak memperlihatkan peningkatan nilai daya tekan setelah hari ke 28. Absennnya kehadiran kapur dalam sedimen ini yang membuat tidak ada peningkatan daya tekan (UCS) karena setelah 28 hari, menurut teori, reaksi semen (hidratasi clinker) hampir selesai setelah 28 hari. Hal ini dapat diverifikasi apabila kita perhatikan bahwa evolusi nilai daya tekan sampel ini (CEM5-LIM0) pada periode curing age dari 28 hari sampai 100 hari hampir sama dengan sampel origin (tanpa binder).

\subsection{Karakteristik Kimia}

Percobaan kimia ini direalisasikan untuk mengidentifikasi kadar polusi dari sedimen hasil pekerjaan pengerukan dari pelabuhan Belawan. Percobaan kimia ini dilakukan dengan metode Toxicity Characteristic Leaching Procedure (TCLP). Percobaan ini dilakukan dengan metode analisis EPA SW 846, jenis metode tergantung atas elemen yang diuji, contohnya untuk Cadmium (Cd), Nickel $(\mathrm{Ni})$, Barium (Ba), Chromium (Cr), Silver (Ag), Cobalt (Co) digunakan metode EPA SW 846AAS dan untuk Selenium (Se) EPA SW 7741AAS. Waktu yang diperlukan dari mulai persiapan sampel hingga hasil untuk menyelesaikan percobaan TCLP ini adalah 7 hari. Hasil dari Percobaan TCLP ini dapat dilihat pada kolom dibawah ini. Hasil percobaan direalisasikan pada sedimen hasil pekerjaan pengerukan pada 2 lokasi yang berbeda (L1 dan L2) dengan 3 sampel untuk mendapatkan variasi mewakili setiap sedimen dilokasi pengambilan. Dari hasil percobaan TCLP dapat kita perhatikan bahwa sedimen berasal dari Alur kolam pelabuhan (L1) menunjukkan hasil yang tinggi dibanding sedimen yang diambil pada depot perbaikan kapal (L2). Hal ini menunjukkan bahwa kegiatan industri pelabuhan di daerah alur kolam lebih berpotensi dalam memproduksi sedimen berpolusi disbanding kegiatan perbaikan kapal. Melalui hasil percobaan TCLP ini juga dapat kita simpulkan bahwa sedimen hasil pekerjaan pengerukan dari Pelabuhan Belawan dapat dikategorikan sedimen dengan tingkat polusi yang cukup penting. Cadmium (Cd) dan Tembaga $(\mathrm{Cu})$ merupakan elemen yang terlihat menunjukkan kwantitas cukup tinggi dalam sedimen Pelabuhan Belawan

Selain $\mathrm{Cd}$ dan $\mathrm{Cu}$, kita dapat memperhatikan juga nilai Zinc $(\mathrm{Zn})$ yang diatas rata-rata nilai rata-rata. Elemen-elemen tersebut apabila mencapai kadar yang tinggi dapat menimbulkan bahaya bahaya (lihat resiko kematian) apabila bersentuhan dengan manusia. Pemerintah Perancis mengeluarkan peraturan menyangkut ambang batas polusi dari sedimen hasil pekerjaan pengerukan. Ambang batas dari polusi tersebut dapat diperhatikan di Tabel 3. Pada tabel dibawah ini terlihat ambang batas dari elemen polusi yang dapat kita katergorikan dalam 3 golongan. Peneliti menggunakan ambang batas ini hanya untuk referensi dikarenakan belum adanya peraturan mengenai ambang batas polusi mengenai sedimen hasil pekerjaan pemerintah di Indonesia. Berdasarkan Ambang batas yang digunakan di Perancis, dapat kita simak bahwa dengan kandungan mereka yang tinggi dalam sampel maka elemen kandungan Cadmium dan Tembaga tergolong dalam kategori limbah berbahaya, dan elemen Zinc termasuk dalam kategori golongan limbah tidak berbahaya. Hal ini tentunya dapat memberikan referensi kepada pemerintah daerah atau instansi terkait agar tidak membuang sedimen hasil pekerjaan pengerukan ke tengah laut, (yang masih dilakukan sampai sekarang) Karena hal tersebut dapat mengakitbakan penyebaran 
sedimen terpolusi dari pelabuhan Belawan ke daerah-daerah sekitarnya. Berdasarkan hasil
TCLP ini diharapkan kegiatan pembuangan sedimen ke tengah laut dihentikan.

Tabel 2. Hasil Percobaan TCLP pada sedimen hasil pekerjaan pengerukan Pelabuhan Belawan

\begin{tabular}{lcccccc}
\hline \multicolumn{1}{c}{ Elemen } & \multicolumn{2}{c}{ Kondisi Origin } & \multicolumn{2}{c}{ Kondisi Origin (2) } & \multicolumn{2}{c}{$\begin{array}{c}\text { Setelah Proses } \\
\text { Pengeringan }\end{array}$} \\
\cline { 2 - 7 } & L1 & L2 & L1 & L2 & L1 & L2 \\
\hline Nickel, Ni & $<0.05$ & $<0.05$ & $<0.05$ & $<0.05$ & $<0.05$ & $<0.05$ \\
Cadmium, Cd & 3.97 & 0.9 & 5.19 & 0.23 & 3.02 & 0.15 \\
Chromium, Cr & $<0.01$ & $<0.01$ & $<0.01$ & $<0.01$ & $<0.01$ & $<0.01$ \\
Copper, $\mathrm{Cu}$ & 2.6 & $<0.01$ & 3.7 & 0.2 & 2,03 & 0.1 \\
Lead, $\mathrm{Pb}$ & $<0.01$ & $<0.01$ & $<0.01$ & $<0.01$ & $<0.01$ & $<0.01$ \\
Zinc, $\mathrm{Zn}$ & 28.8 & 10.4 & 37.1 & 17.2 & 21.3 & 9.04 \\
Mercury, Hg & $<0.0002$ & $<0.0002$ & $<0.0002$ & $<0.0002$ & $<0.0002$ & $<0.0002$ \\
Arsenic, As** & $<0.002$ & $<0.002$ & $<0.002$ & $<0.002$ & $<0.002$ & $<0.002$ \\
Nitrit, NO2 & 0.03 & 0.03 & 0.03 & 0.03 & 0.03 & 0.03 \\
Silver, Ag & $<0.01$ & $<0.01$ & $<0.01$ & $<0.01$ & $<0.01$ & $<0.01$ \\
Cobalt, Co & $<0.05$ & $<0.05$ & $<0.05$ & $<0.05$ & $<0.05$ & $<0.05$ \\
\hline
\end{tabular}

Tabel 3. Referensi ambang polusi sedimen hasil pengerukan di Eropah

\begin{tabular}{lcc}
\multicolumn{1}{c}{ Elemen } & $\mathbf{N 1}$ & $\mathbf{N}$ \\
& Batas limbah tidak berbahaya & Batas limbah Berbahaya \\
\hline Nickel $(\mathrm{Ni})$ & 37 & 74 \\
Cadmium $(\mathrm{Cd})$ & 1.2 & 2.4 \\
Chromium $(\mathrm{Cr})$ & 90 & 180 \\
Copper $(\mathrm{Cu})$ & 45 & 90 \\
Lead $(\mathrm{Pb})$ & 100 & 200 \\
Zinc $(\mathrm{Zn})$ & 276 & 552 \\
Mercury $(\mathrm{Hg})$ & 0.4 & 0.8 \\
Arsenic $(\mathrm{As})$ & 25 & 50 \\
\hline
\end{tabular}

\section{Kesimpulan}

Penelitian ini direalisasikan untuk mencari aplikasi reutulisasi sedimen hasil pekerjaan pengerukan sehingga tindakan pembuangan sedimen hasil pekerjaan pengerukan tersebut dapat dihentikan. Hal ini diperkuat oleh percobaan kimia melalui percobaan TCLP, hasil yang diperoleh menunjukkan sedimen mengandung elemen $\mathrm{Cu}$ dan $\mathrm{Cd}$ yang cukup tinggi, dan apabila diperbandingkan dengan referensi batas polusi sedimen yang digunakan di Eropah, Sedimen tersebut termasuk dalam kategori limbah berbahaya. Karakteristik mekanik dari sedimen origin berdasarkan penelitian yang dilakukan menunjukkan bahwa sedimen terkait termasuk dalam kategori tanah liat dengan plastisitas rendah, dengan ukuran majoritas sekitar 66-78 $\mu \mathrm{m}$. Percobaan Proctor dan CBR menunjukkan bahwa sedimen tersebut dengan campuran binder seperti semen dan kapur dengan persentase kapur 10\% menunjukkan hasil IPI yang tertinggi. Efek dari binder semen maupun kapur dapat diidentifikasi melalui percobaan daya tekan (unconfined compressive strength). Melalui percobaan ini diketahui bahwa penambahan kwantiti semen mempengaruhi performa mekanik pada periode curing age jangka pendek (7-14 hari) dan penambahan kwantiti persentase kapur mempengaruhi performa mekanik pada periode curing age jangka panjang (60-100 hari). Pengaruh kadar limbah pada sedimen juga diidentifikasi melalui percobaan ini, dimana sedimen L1 (dengan kadar polusi lebih tinggi) memperlihatkan performa mekanik lebih rendah dibanding L1. Komposisi binder yang menghasilkan performa mekanik terbaik adalah komposisi dengan 5\% semen dan 5\% kapur. Sampel dengan komposisi diatas tersebut dapat digunakan dalam pekerjaaan pembangunan jalan dimana 
persyaratan nilai daya tekan diatas $1 \mathrm{MPa}$ dapat dipenuhi oleh sampel.

\section{Daftar Pustaka}

Colin D (2004) Valorisation des sédiments fins de dragage en technique routière Tesis Doktor, l'Université de Caen, 323 halaman [2] Situmorang, M., Sinaga,.M., Tarigan, D.A., Sitorus, C.J, dan Tobing, A.M.L., (2011), The Affectivity of Innovated Chemistry Learning

Javad BEHMANESH (2008) Etude de la durabilité d'un sédiment, traité au ciment et additifs. Tesis Doktor, l'Université de Caen. 214 halaman

Silitonga E., Levacher D., Mezazigh S., (2009) Effects of the use of fly ash as a binder on the mechanical behaviour of treated dredged sediments; Environmental Technology, Volume 3 Published by Taylor and Francis Group.

Duan ZHIBO (2008) Caractérisation, stabilisation et solidification de sédiment marin, Tesis Doktor, Université de Caen, 245 halaman

Detzner, H. D., A. Netzband, et al. (2004) Dredged Material Management in Hambur, Terra et Aqua 96(September): 314

Heise, S., E. Claus, et al. (2005) Studie zur Schadstoffbelastung der Sedimente im Elbeeinzugsgebiet. Ursachen und Trends. Hamburg, Hamburg Port Authority: 195

Silitonga E., Shrivastava A., Levacher D. (2008) Influence of fly ash addition on the mechanical properties of treated dredged material. Proceeding of International Symposium on Sédiment Management, Lille, France, 9-11 Juillet 2009

Silitonga E., Mezazigh S., Levacher D. (2008) Investigating the influence of dredged material stabilized by pozzolanic binders on geotechnical properties. Proceeding of Xèmes Journées Nationales Génie Côtier-Génie Civil, Sophia Antipolis, France, 14-18 Octobre 2008.

Silitonga E., Levacher D., Mezazigh S., (2009) Effects of the use of fly ash as a binder on the mechanical behaviour of treated dredged sediments; Environmental Technology,
Volume 3 Published by Taylor and Francis Group

Ernesto SILITONGA Valorisation des sédiments marins contaminés par solidification/ stabilisation à base de liants hydrauliques et de fumée de silice» Tesis Doktor, Université de Caen, 267 hal 